原 著(Original Contribution): 膜 (MEMBRANE), 14(1), 71-76 (1989)

\title{
圧力こう配下における荷電膜の緩和現象
}

\author{
田坂雅保・宮原信弘
}

信州大学工学部工業化学科 $\mathbf{T} 380$ 長野市若里 500

\section{Relaxation Phenomena of Charged Membranes under Pressure Gradient}

\author{
Masayasu TASAKA • Nobuhiro MIYAHARA
}

Department of Industrial Chemistry, Faculty of Engineering, Shinshu University, 500 Wakasato, Nagano 380

The dependence of streaming potential on time was measured by applying a pressure difference across aglass filter membrane, a cellulose acetate membrane, a collodion-polystyrenesulfonic acid membrane, a collodion-polyacrylic acid membrane, and a collodion-polyacrylic acid partially complexed with Fe (III)ions membrane. The streaming potential reached immediately a constant value after pressure difference was applied across the membrane, if the membrane was made of substances having stiff structure. However, the absolute value of the streaming potential across the membrane made of soft structure increased slowly with time and a long time was required to reach a steady state. Therefore, the properties of membranes can be characterized by analyzing the dependence of streaming potential on time.

Key words : Relaxation phenomena, Charged membranes, Pressure gradient, Streaming potential.

\section{要 旨}

ガラス膜, 酢酸セルロース膜, コロジオンーポリスチ レンスルホン酸膜, コロジオンーポリアクリル酸膜, な らびに鉄イオンで橋かけしたコロジオン一ポリアクリル 酸膜の両側に圧力差をかけ, 膜を通しての流動電位の時 間的変化を測定した. 硬い物質構造から成る膜を使用し た場合には, 流動電位は圧力差をかけた瞬間に定常状態 に達した. しかし, 軟らかい物質構造から成る膜を使用 した場合には, 流動電位は時間とともに徐々に増大して いき, やがて定常状態に達することが観測された. した がって, 圧力差をかけてからの, 流動電位の定常状態に 達するまでの時間的変化を測定することによって, 膜を 構成する物質の特性を知ることが明らかになった。

\section{1. 緒 言}

多孔質な膜の両側に同一濃度の電解質溶液を入れ, 圧 力差 $\Delta P$ をかけると体積流 $J_{V}$ が生じ, 体積流と膜の固
定電荷との間の相互作用の結果, 流動電位 $\Delta \phi_{s t}$ が発生 する．膜が高分子からできている場合，圧力差 $\Delta P$ をか けると流動電位 $\Delta \psi_{s t}$ は時間と共に少しずつ変化するこ とが古くから知られている. Schmidt ら"や Brun ら ${ }^{2)}$ はこの $\Delta \psi_{s}$ の時間的変化は, $\Delta P$ にっって膜の両側に 生ずる濃度差 $\Delta c_{s}$ が次第に増大し, その結果発生する 濃淡膜電位が原因と考えた. しかし，この時間的変化が 膜の固定電荷濃度よりもむしろ膜の種類に大きく依存し ていることを考えると, 膜内部における構造の変化が影 響しているものと考えられる.この論文では, 膜の種類 を変えて $\Delta \phi_{s t}$ の時間的変化を測定し膜構造による影響 を検討した。

膜の両側で温度差と濃度差がない場合の不連続系での 散逸関数 $\Phi$ は

$$
\Phi=\left(-J_{V}\right) \Delta P+(-I) \Delta \phi
$$

で示され ${ }^{3.1)}$, 定常状態における流束と力との間の現象 論的方程式は, 


$$
\begin{aligned}
& -J_{V}=L_{11} \Delta P+L_{12} \Delta \phi \\
& -I=L_{21} \Delta P+L_{22} \Delta \phi
\end{aligned}
$$

之書けることが知られている. 膜に一定の大きさの外力 がかけられた場合, 膜が時間とともに形態変化を起こす ならば，現象論的係数 $L_{i j}$ は時間とともに変化し時間 の関数として表現される. (2), (3) 式の線形関係が成立 するような力 $\Delta P$ や $\Delta \phi$ の範囲内では, 静止状態から 定常状態に達する過程においても, 時刻 $t$ において

$$
\begin{aligned}
& -J_{V}(t)=L_{11}(t) \Delta P+L_{12}(t) \Delta \phi \\
& -I(t)=L_{21}(t) \Delta P+L_{22}(t) \Delta \phi
\end{aligned}
$$

の関係が成立するであろう。したがって, $I=0$ の条件 下で，一定の大きさの圧力差 $\Delta P$ をかけたときの流動電 位 $\Delta \phi_{s t}$ は時間の関数となり

$$
\Delta \phi_{s t}(t)=\left[-L_{21}(t) / L_{22}(t)\right] \Delta P
$$

と示される.

\section{2. 実 験}

\section{$2 \cdot 1$ 膜}

膜としては平均孔径 $5 \mu \mathrm{m}$ の SANSYO ガラスフィ ルター G4 (GF), 平均孔径 $0.05 \mu \mathrm{m}$ から成る酶酸セル ロース系のザートリウスメンブランフィルター (MF12), コロジオンとポリスチレンスルホン酸 (10\%) のイ ンターポリマー膜 (C-PSS), コロジオンとポリアクリ ル酸 $(30 \%)$ のインターポリマー膜 (C-PA), C-PA 膜 を $0.1 \mathrm{M} \mathrm{FeCl}{ }_{3}$ 中で 30 分浸し $\mathrm{Fe}$ (III) で橋かけした膜 (C-PA-Fe) を用いた。

\section{$2 \cdot 2$ 溶液}

電解質溶液としては 0.001 と $0.003 \mathrm{~mol} / \mathrm{kg} \mathrm{KCl}$ 溶液 を用いた。

\section{$2 \cdot 3$ 流動電位測定}

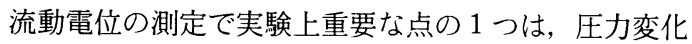
に対して安定な電極を使用することである ${ }^{5}{ }^{6}{ }^{6)}$. 電極之 しては銀塩化銀電極を使用した．銀塩化銀電極は純銀板 上に $0.4 \mathrm{~mA} / \mathrm{cm}^{2}$ の電流密度で電解することにより, 一面にうっすらと塩素化を行って作製した. 膜の両側の 溶液をかき混ぜたときの溶液の対流による電極電位への 影響を小さくするために，電極の周りに小さなカバーを取 り付けた. 膜の両側の圧力差は, 静水圧により $\pm 10 \mathrm{kPa}$ の範囲内で変化させた. 膜の両側の圧力差を振動させた とき使用したセルの模型図を Fig. 1 に示す. 圧力差の 切り替えはガラス製のコックを用いて行った。電位差計

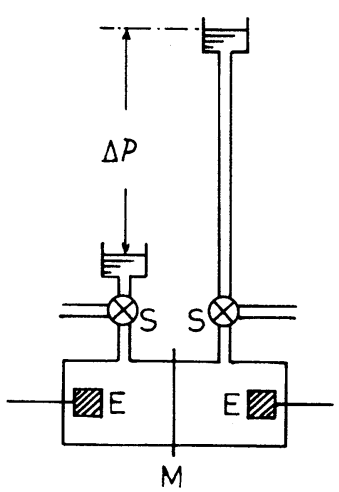

(A)

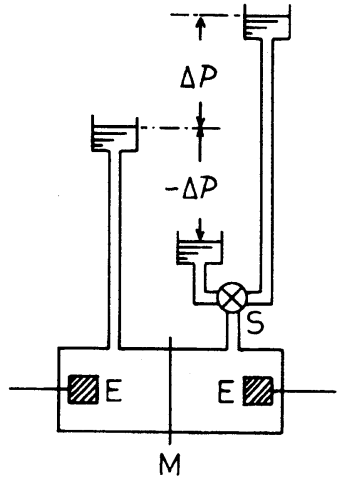

(B)
Fig. 1 Schematic diagram of the cells for measuring streaming potential.

E, silver/silver chloride electrode ; $\mathrm{M}$, membrane ; S, three-way stopcock ; pressure difference.

としてはタケダ理研工業(株)の TR-8651 と TR-8411 を, 圧力測定のための圧力センサーとしては豊田工機 (株) の拡散形半導体小形圧力変換器 $0.3 \mathrm{~F}-2.14$ 之直流 増幅機 AA-3004 を使用し, 理化電機工業(株) の多ペン レコーダー002を用いて $\Delta \phi_{s t}$ の時間的変化を記録した。

\section{3. 結果と考察}

Cooke はガラスフィルターを用いて圧力差を 1 秒間 に 1 400 回振動させて流動電位を測定した. 振動数が 小さくなるとその值は増加して一定になることを報告し ている7). 本実験でも, $0.001 \mathrm{~mol} / \mathrm{kg} \mathrm{KCl}$ 溶液で Fig. $1 \mathrm{~A}$ の装置を用いて圧力差 $\Delta P$ を 0 と $41 \mathrm{~cm}-\mathrm{H}_{2} \mathrm{O}$ に周 期的に変化させて測定した. ガラスフィルター (GF) を 用いた場合の流動電位の変化は, Fig. 2 に示されてい るように, 1 分間に 2 30 回の振動数では振動数によら ず $41 \mathrm{~cm}-\mathrm{H}_{2} \mathrm{O}$ の $\Delta P$ にたいして一定の $17 \mathrm{mV}$ を示し ている. Fig. 2 で圧力の切り替えをガラス製のコック で行い, 装置との関係上切り替えの瞬間に逆方向に小さ な圧力の変化が生じたため, その影響が流動電位の変化 にも現われている。

同じ $0.001 \mathrm{~mol} / \mathrm{kg} \mathrm{KCl}$ 溶液中でも, 高分子膜 C-PA について $\Delta P$ を 0 と $63 \mathrm{~cm}-\mathrm{H}_{2} \mathrm{O}$ と変化させたときは, 切り替え時間を $5,10,30 \mathrm{~s}$ に設定すると, $\Delta \phi_{s t}$ は 1.7 , 1.9, $2.4 \mathrm{mV}$ と增大する (Fig. 3 参照). 同様の傾向 が, C-PSS 膜についても観測された.

$0.001 \mathrm{~mol} / \mathrm{kg} \mathrm{KCl}$ 溶液を用い, Fig. 1B の装置で圧 
Table 1. Properties of membranes

\begin{tabular}{|l|l|l|l|}
\hline Membrane & $\begin{array}{l}\text { Transport number } \\
\text { of cations in } \\
0.001-0.002 \mathrm{~mol} / \mathrm{kg} \\
\text { KC l }\end{array}$ & $\begin{array}{l}\text { Water content } \\
\text { (g/g of dry } \\
\text { membrane) }\end{array}$ & $\begin{array}{l}\text { Thickness } \\
(\mathrm{mm})\end{array}$ \\
\hline GF & -- & 0.26 & 4.85 \\
MF-12 & -- & 1.11 & 0.07 \\
C-PSS & 0.87 & 4.70 & 0.21 \\
C-PA & 0.87 & 9.16 & 0.29 \\
C-PA-Fe & 0.65 & 5.71 & 0.21 \\
\hline
\end{tabular}

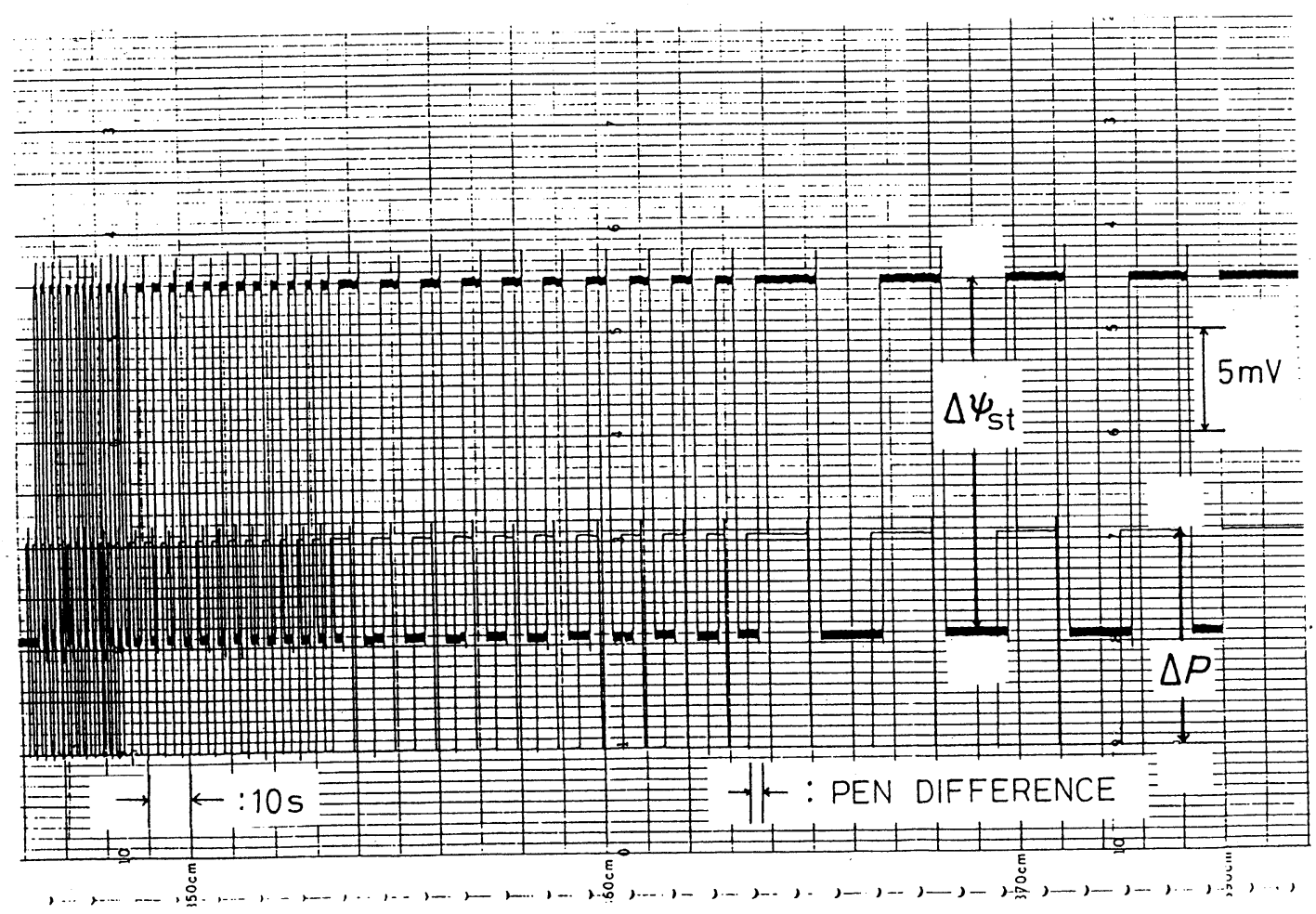

Fig. 2 Dependence of streaming potential $\Delta \phi_{s t}$ across glass filter membrane GF on time in $0.001 \mathrm{~mol} / \mathrm{kg} \mathrm{KCl}$ solution when the prossure difference $\Delta P(41$ $\mathrm{cm}-\mathrm{H}_{2} \mathrm{O}$ ) is periodically applied by the cell shown in Fig. $1 \mathrm{~A}$.

力差 $\Delta P$ を $\pm 20, \pm 33, \pm 47, \pm 60 \mathrm{~cm}-\mathrm{H}_{2} \mathrm{O}$ と変化さ せたときの膜 C-PA についての流動電位の時間的変化 をFig. 4 に示した. 圧力差 $\Delta P$ が大きいほよ゙ $\Delta \phi_{s}$ も も大 きいことがわかる.ある時刻 $t$ における流動電位 $\Delta \phi_{s t}(t)$ を定常状態における流動電位の絶対值 $\left|\Delta \phi_{s t}(\infty)\right|$ で 割った值を還元流動電位 $\Delta \phi_{s t}^{r}(\mathrm{t})$ と定義する.

$$
\Delta \phi_{s t}^{r}(t) \equiv \Delta \phi_{s t}(t) /\left|\Delta \phi_{s t}(\infty)\right| \quad(7)
$$

各圧力差で測定された流動電位から還元流動電位を求め 図示すると, 実線で示した曲線がえられた。還元流動電 位は圧力差に関係なく, 実験誤差内において 1 本の曲線で 示された. 同様の結果が, $0.003 \mathrm{~mol} / \mathrm{kg} \mathrm{KCl}$ 溶液之膜 C-PSS について Fig. 5 に示されている. $\Delta P$ と $\Delta \psi_{\text {st }}$ の間に直線関係が成立するような，圧力差が余り大きく ない範囲では, 膜に特有の流動電位の時間的变化を還元 


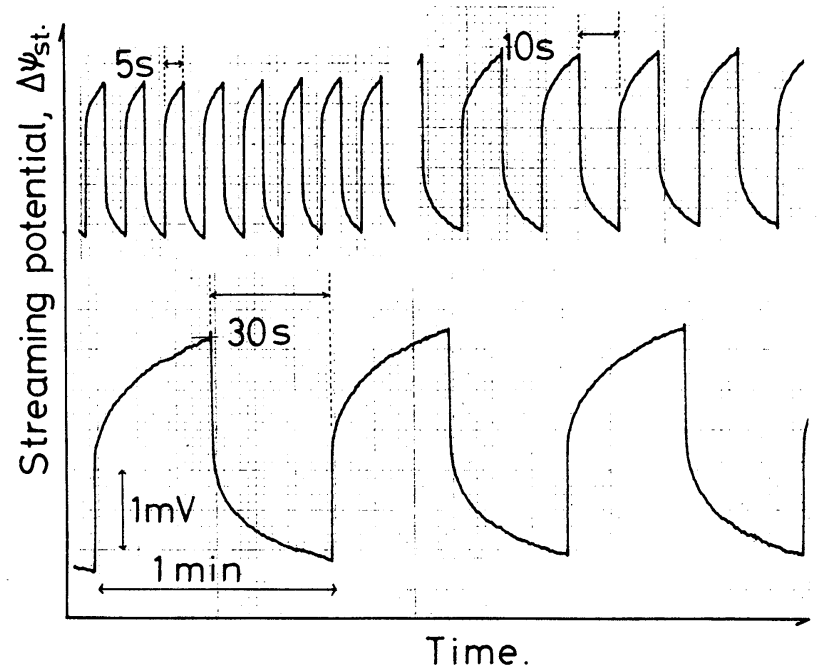

Fig. 3 Dependence of streaming potential $\Delta \psi_{s}$ across collodion-poly (potassium acrylate) membrane $\mathrm{C}-\mathrm{PA}$ on time in $0.001 \mathrm{~mol} / \mathrm{kg} \mathrm{KCl}$ solution when the pressure difference $\Delta P\left(63 \mathrm{~cm}-\mathrm{H}_{2} \mathrm{O}\right)$ is periodically applied at 5,10 and $30 \mathrm{~s}$ intervals, respectively, by the cell shown in Fig. $1 \mathrm{~A}$.

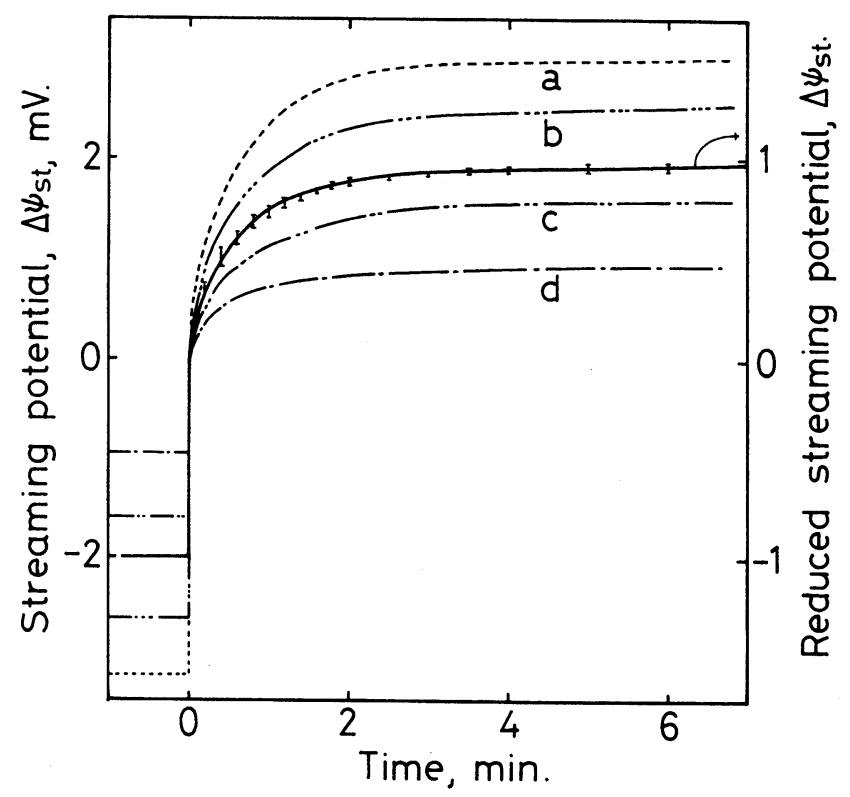

Fig. 4 Dependence of streaming potential $\Delta \phi_{s t}$ on time is indicated by broken lines $\mathrm{a}, \mathrm{b}, \mathrm{c}$ and $\mathrm{d}$ where the data were measured under $\pm \Delta P\left(\mathrm{~cm}-\mathrm{H}_{2} \mathrm{O}\right)$ : $60,47,33$ and 20, respectively, by the cell shown in Fig. $1 \mathrm{~B}$. Dependence of reduced streaming potential $\Delta \psi_{s t}^{r}$ on time is indicated by the solid line. Membrane : collodion-poly (potassium acrylate) C-PA. Solution : 0.001 $\mathrm{mol} / \mathrm{kg} \mathrm{KCl}$. 


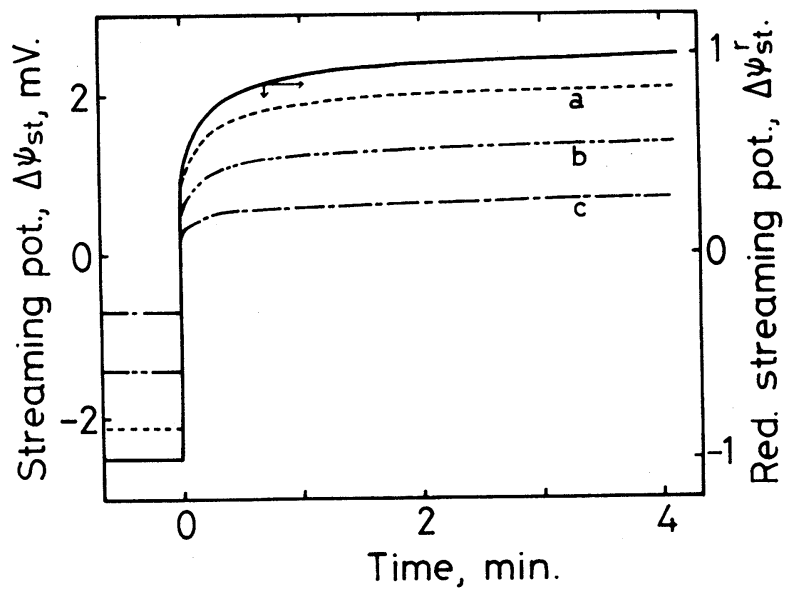

Fig. 5 Dependence of streaming potential $\Delta \phi_{s t}$ on time is indicated by broken lines $\mathrm{a}, \mathrm{b}$ and $\mathrm{c}$ where the data were measured under $\pm \Delta P\left(\mathrm{~cm}-\mathrm{H}_{2} \mathrm{O}\right)$ : 60,40 and 20, respectively, by the cell shown in Fig. 1 B. Dependence of reduced streaming potential $\Delta \phi_{s}^{r}$, on time is indicated by the solid line.

Membrane : collodion-poly (potassium styrenesulfonate) membrane C-PS S. Solution : $0.003 \mathrm{~mol} / \mathrm{kg} \mathrm{KCl}$.

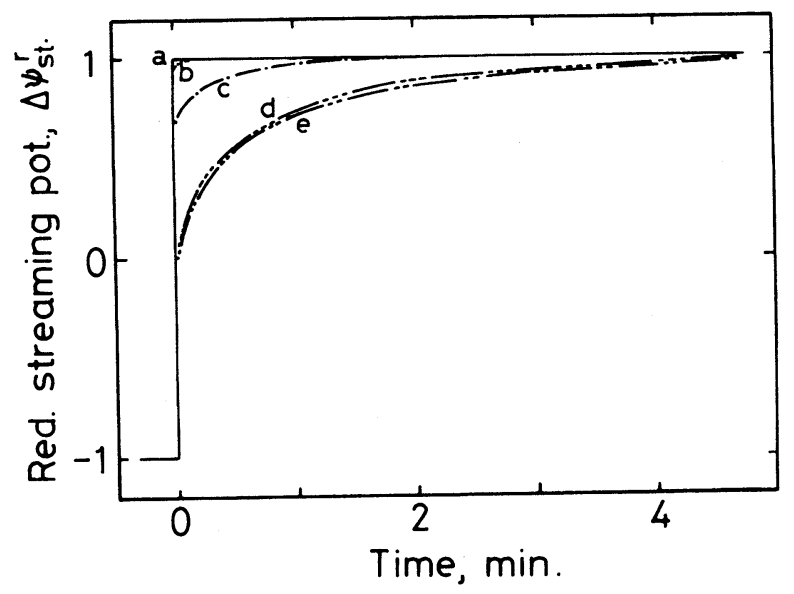

Fig. 6 Dependence of reduced streaming potential on time in $0.001 \mathrm{~mol} / \mathrm{kg} \mathrm{KCl}$ solution.

Membranes ; a, glass filter GF ; b, cellulose acetate MF-12 ; c, collodionpoly (potassium acrylate) partially complexed with Fe (III) C-PA-Fe ; d, collodion-poly (potassium styrenesulfonate); e, collodion-poly (potassium acrylate).

流動電位を用いて示すことができる.

種々の荷電膜について, $0.001 \mathrm{~mol} / \mathrm{kg} \mathrm{KCl}$ 溶液での 還元流動電位の時間的变化を示すと Fig. 6 がえられる. 膜C-PA と膜 C-PA-Fe を比較すると, 膜内の溶液相 に長いポリアクリル酸の鎖が溶けていると考えられる
膜 C-PA では, 定常状態に達するまでの時間が長く, ポリアクリル酸の鎖の途中を鉄イオンで橋かけがなされ 自由に動ける鎖が短くなっている膜 C-PA-Fe では, 定常状態に達するまでの時間は短くなっている. また, ビニル系ポリマーと比較して，硬い鎖からできている 


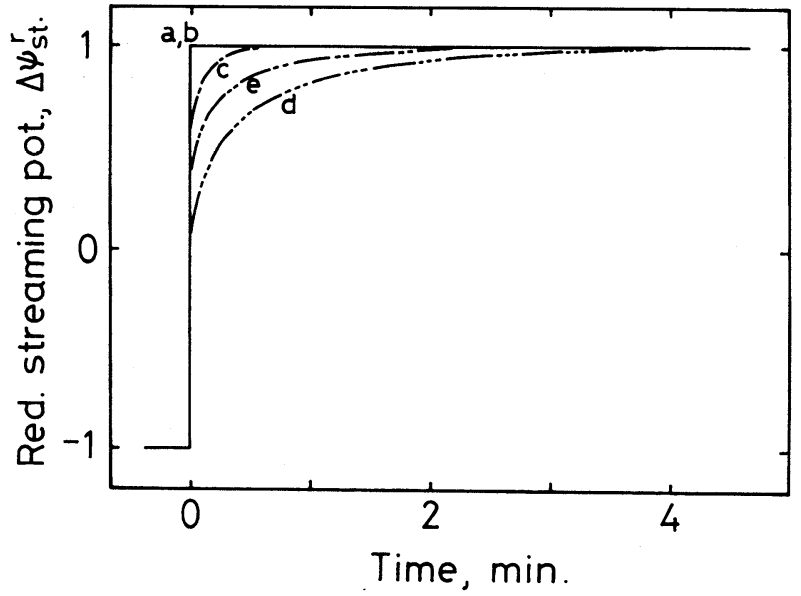

Fig. 7 Dependence of reduced streaming potential on time in $0.003 \mathrm{~mol} / \mathrm{kg} \mathrm{KCl}$ solution. Notations are the same as in Fig. 6.

之考えられる酢酸セルロース系の膜 MF-12 の場合も定 常状態に達するまでの時間は短くなっている. Fig. 2 でも示したように, ガラス膜 GF では瞬間的に定常状 態に達している.

$0.003 \mathrm{~mol} / \mathrm{kg} \mathrm{KCl}$ 溶液での同様の結果が Fig. 7 に 示されている. 外部溶液の電解質濃度が高くなると, 膜 内の副イオン濃度も高くなり, 膜内溶液中に溶けている 高分子電解質の鎖の広がりも小さくなり, 定常状態に達 するまでの時間も短くなるものと考えられる.

Kumahr らもイオン交換膜を用いて流動電位の時間 的変化を測定している ${ }^{8)}$. 彼らは流動電位の時間的変化 の原因を電気二重層の形成に関する緩和現象と解釈して いる. しかし, 膜の種類を変えたときの流動電位の大き な時間的変化は電気二重層の形成に関する緩和だけでは 説明できない，膜内の高分子鎖の形態变化が大きく関与 しているものと思われる.

Fig. 6, 7 に示された曲線から膜の主要な緩和要素に対 応する遅い部分の緩和時間 $\tau$ を求めると, $0.001 \mathrm{~mol} / \mathrm{kg}$ $\mathrm{KCl}$ の中では, それぞれ $\tau(\mathrm{C}-\mathrm{PSS})=85 \mathrm{~s}, \tau(\mathrm{C}-\mathrm{PA})$ $=63 \mathrm{~s}, \tau(\mathrm{C}-\mathrm{PA}-\mathrm{Fe})=26 \mathrm{~s}$ であり, $0.003 \mathrm{~mol} / \mathrm{kg} \mathrm{KCl}$ 中では, それぞれ $\tau(\mathrm{C}-\mathrm{PSS})=55 \mathrm{~s}, \tau(\mathrm{C}-\mathrm{PA})=46 \mathrm{~s}$, $\tau(\mathrm{C}-\mathrm{PA}-\mathrm{Fe})=20 \mathrm{~s}$ と短くなっている. しかし, 詳細 に検討すると, コロジオンと高分子電解質からできて いるインターポリマー膜では, 構成成分も複数から
成っており, 緩和過程に寄与する要素も複数存在する と考えられる.これらの検討には, 流動電位の時間的 変化の精度高い測定と解析が必要である。続報におい て詳細に検討する予定である.

以上みてきたように，流動電位の時間的変化は膜を構 成する膜内溶液層の性質を反映しており，膜のキャラク タリゼーションに役立つものと思われる.

\section{文献}

1) G.Schmidt, H. Schwartz, Z. Elektrochem., 56, 35 (1952)

2) T. S. Brun, D. Vaula, Ber. Bunsenges. Phys. Chem., 71, 835 (1967)

3) S.R. de Groot and P. Mazur, Non-Equilibrium Thermodynamics. North-Holland Publishing Co., Amsterdam (1962)

4) A. Katchalsky and P. F. Curran, Nonequilibrium Thermodynamics in Biophysics, Harvard Univ. Press, Cambridge, Massachusetts (1965)

5) M. Tasaka, S. Tamura, N. Takemura, K. Morimoto, J. Membrane Sci., 12, 169 (1982)

6) 田村 諭, 山崎 隆喜, 田坂 雅保, 高分子論文 集, 34, 719 (1977)

7) C. E. Cooke, Jr., J. Chem. Phys., 23, 2299 (1955)

8) R. Kumar, K. Singh, Indian J. Chem., 19A, $511(1980)$ 